\title{
Structure of Diatom Assemblages Living on Prop Roots of the Red Mangrove (Rhizophora mangle) from the West Coast of Baja California Sur, México ${ }^{1}$
}

\author{
David Siqueiros-Beltrones, ${ }^{2,3,4}$ F. Omar López-Fuerte, ${ }^{3}$ and Ismael Gárate-Lizárraga ${ }^{3}$
}

\begin{abstract}
Samples of epiphytic diatom assemblages found on prop roots of red mangrove (Rhizophora mangle) from four sites were collected at two tidal levels of exposure on two different dates from the cool season (autumn, spring). The overall floristic analysis yielded 171 diatom taxa, including 16 new records for the Baja California peninsula. Diversity estimates were among the highest ever measured for benthic diatoms using Shannon's (mean $\mathrm{H}^{\prime}=4.89$ ) and Simpson's (0.945) indices. Many species scored high on the Biological Value Index (BVI), thus reflecting their numerical importance within the assemblages. According to diversity values and overall species composition, all sampling sites represented a similar habitat consisting of three types of substrates: prop roots, epiphytic macroalgae, and sediments. These values are considered to represent stability in the diatom assemblages living on red mangrove prop roots. Thus, the conditions determined by periodic tidal exposure are not to be considered extreme. However, principal component analysis and similarity measurements indicated that the November and April assemblages could be discriminated on the basis of taxa distribution.
\end{abstract}

Mangrove systems are often found in tropical and subtropical coastal lagoons. Mangroves occur along most of the western Mexican coast. In the Sea of Cortés (Gulf of California) they reach as far as $30^{\circ} \mathrm{N}$; along the western coast of the Baja California peninsula the Bahía Magdalena-Almejas lagoon system $\left(25^{\circ} \mathrm{N}\right)$ represents their northernmost distribution (Blasco 1984). In Baja California

\footnotetext{
${ }^{1}$ Financial support for this study was provided in part by CGPI-IPN-2001-0319 and CGPI-20020373. D.S.-B. and I.G.-L. are Comisión de Operación y Fomento de Actividades Académicas and Estímulo al Desempeño de los Investigadores fellows. Manuscript accepted 4 May 2004.

${ }^{2}$ Corresponding author.

${ }^{3}$ Centro Interdisciplinario de Ciencias Marinas (CICIMAR-IPN), A.P. 592, La Paz, B.C.S. (e-mail: dsiquei@ipn.mx).

${ }^{4}$ Departamento de Biología Marina, Universidad Autónoma de Baja California Sur, A.P. 19-B, La Paz, B.C.S. (e-mail: beltron@uabcs.mx).
}

Pacific Science (2005), vol. 59, no. 1:79-96

(C) 2005 by University of Hawai'i Press

All rights reserved
Sur (B.C.S.) mangrove systems have a discontinuous distribution and are composed of three species: red mangrove (Rbizophora mangle L.), black mangrove (Avicennia germinans (L.) Stearn), and white mangrove ( $\mathrm{La}$ guncularia racemosa (L.) Gaertner).

As in most shallow marine systems benthic diatoms play an important role as primary producers and as main constituents of microbial communities in mangrove systems, where they aid in stabilizing and preventing desiccation of the sediments (Navarro 1988, Siqueiros Beltrones and Sánchez Castrejón 1999, Cahoon and Safi 2002). They are also an important food source for many microand macroscopic invertebrates as well as for filter feeders in the form of tychoplankton (Navarro 1988). Benthic diatoms use different types of substrates including mangrove roots, such as the pneumatophores of black mangrove or the prop roots of red mangrove. Floristics on benthic diatoms carried out expressly for mangrove systems are scarce, although several floristic studies have considered these habitats (Foged 1975, 1984, Sullivan 1981, Navarro 1982, Maples 1983, Wah and Wee 1988). 
However, approximations of the assemblage structure of diatoms living on prop roots of mangroves are available. These show that few species may be occupying the surface of pneumatophores of black mangrove (Maples 1983), or that various numbers of diatom taxa, either low (Reyes-Vázquez 1975), intermediate (Sullivan 1981), or high (Navarro 1982, Navarro and Torres 1987), may be found on prop roots of red mangroves. Moreover, high values of diversity have been estimated in several studies carried out in different mangrove systems (Sullivan 1981, Navarro 1987, Siqueiros Beltrones and Sánchez Castrejón 1999).

In mangrove systems of B.C.S. as many as 289 diatom taxa have been recorded from sediments (Siqueiros Beltrones and Sánchez Castrejón 1999, Siqueiros Beltrones and Morzaria Luna 1999). The first observations on the diatom associations of red mangrove prop roots from Bahía Magdalena, B.C.S. (Siqueiros Beltrones and López Fuerte 2003) revealed a high number of taxa, several of which were abundant on macroalgae epiphytic on the prop roots. More than 25\% of these species had been recorded as common constituents of the phytoplankton along with benthic diatom taxa from different substrates (Gárate Lizárraga and Siqueiros Beltrones 1998, Gárate Lizárraga et al. 2000, 2001, Martínez López and Verdugo Díaz 2000, Gárate Lizárraga and Verdugo Díaz 2001).

In this study a floristic inventory of epiphytic diatoms on mangrove prop roots from Bahía Magdalena was extended and the structure of the assemblages is further described, which, from previous results, was expected to yield high species diversity and species richness as is usually found in highly productive systems. In addition, we explore the influence of seasonal changes and of exposure to desiccation on the structure of the diatom assemblages.

\section{Study Area}

Bahía Magdalena is a shallow lagoon located on the western coast of Baja California Sur $\left(24^{\circ} 15^{\prime}-25^{\circ} 20^{\prime} \mathrm{N}, 111^{\circ} 30^{\prime}-112^{\circ} 12^{\prime} \mathrm{W}\right)$ (Figure 1). It is part of the Bahía MagdalenaBahía Almejas lagoon system, which is densely populated by mangroves: mainly Rhizophora mangle bordering the coastline and Avicennia germinans farther inland. This lagoon system may be divided into three zones. The northern zone consists of a series of channels with a mean depth of $3.5 \mathrm{~m}$. The central part is known as Bahía Magdalena and is connected to the ocean by a wide opening. The southeastern zone, Bahía Almejas, is connected to Bahía Magdalena by a narrow mouth. The system is considered an antiestuary with irregular bathymetry. Rich upwelling waters enter the lagoon on incoming tides, and high concentrations of phytoplankton are exported to the ocean on ebbing tides (Guerrero et al. 1988). The system exhibits a mixed semidiurnal tidal regime. Ranges of 1.16 and 1.46 $\mathrm{m}$ have been measured in localities inside the bay (Obeso Nieblas et al. 1999). Mean minimum and maximum salinities and temperatures were recorded in Bahía Magdalena by Alvarez-Borrego et al. (1975) as 34.08$39.2 \mathrm{psu}$ and $17-28^{\circ} \mathrm{C}$, and temperatures by Gárate-Lizárraga et al. (2001) as 16.7$29.8^{\circ} \mathrm{C}$. In the study reported here, four sampling sites located in the Puerto San Carlos docking area (Figure 1) were chosen on the basis of their similarity; these represented a nearly homogeneous area characterized by muddy sediments where red mangrove prop roots were anchored.

\section{MATERIALS AND METHODS}

Samples were collected in Bahía Magdalena during November (autumn) 1999 and April (spring) 2000, between ca. 1000 and 1200 hours. In November two sites (1 and 2) were sampled, and in April two more sites (3 and 4) were added to the sampled area. The sampling sites were approximately $50 \mathrm{~m}$ apart. Samples were taken during low tide when the roots were exposed. Bark segments $30 \mathrm{~cm}^{2}$ in area $(2$ by $15 \mathrm{~cm})$ were peeled off from two areas of the red mangrove prop roots: damp segments (lower level) from the bottom, and dry segments (upper level) just below $90 \mathrm{~cm}$ up, limited by the high-tide mark on the roots. Exposure time of upper and lower parts of the prop roots to desiccation was ca. 12 and $6 \mathrm{hr}$, respectively. Each sample was composed of three segments (from three roots of 


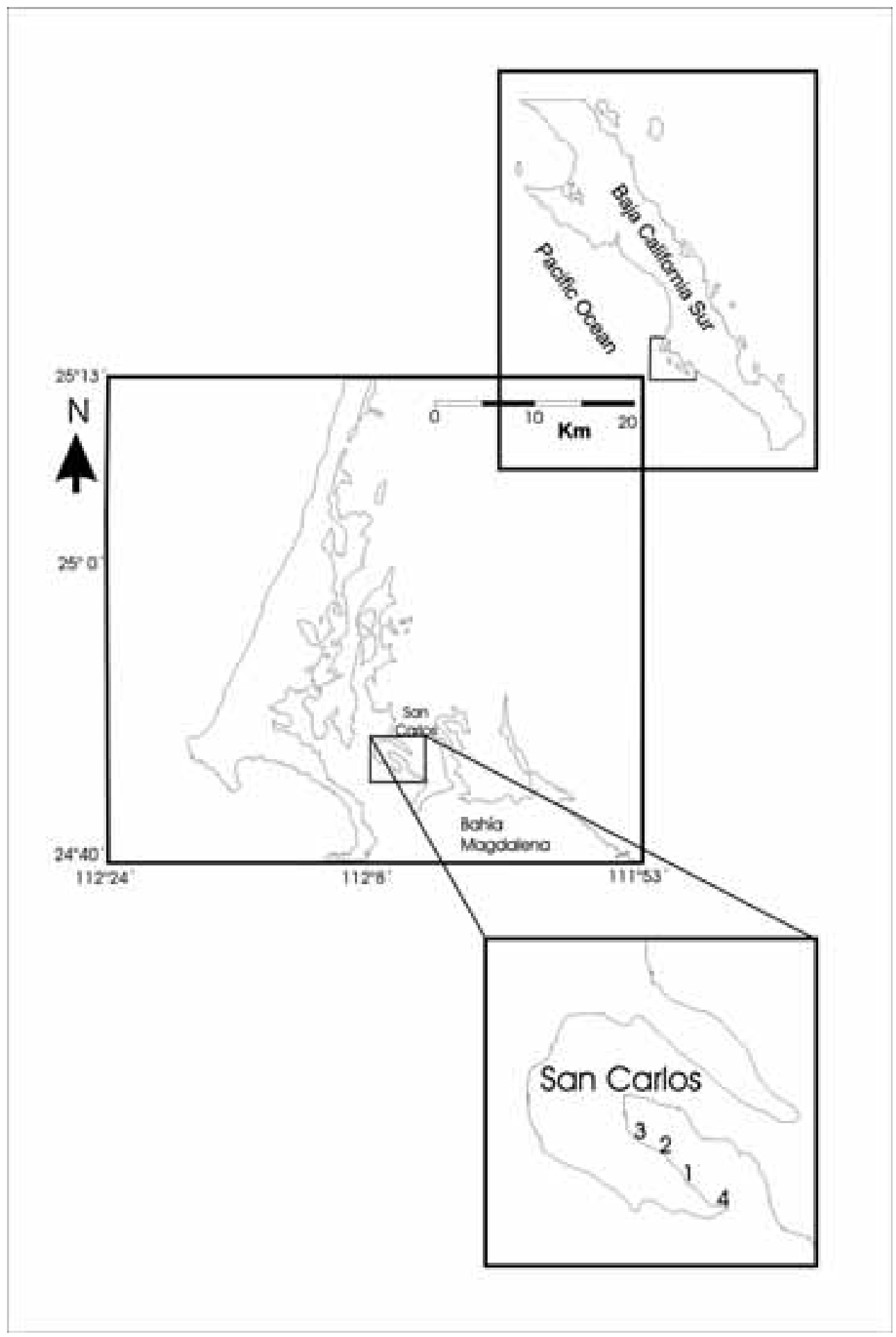

Figure 1. The Bahía Magdalena lagoon system and location of sampling sites. 
the same tree). During November a total of 12 segments was collected (four samples), and in April a total of 24 segments (eight samples) was collected. Air temperature was recorded with a field thermometer. Because desiccation is considered the main factor determining the presence/absence of diatom taxa on exposed prop roots of Rhizophora mangle, and these were covered partially with sediments, salinity in the exposed bottom sediments was measured. This was done using a refractometer by squeezing out a drop of water from the sediments through filter paper.

All visible epiphytic macroalgae found (only on the lower-level segments) were removed from each bark strip under a dissecting microscope and were studied separately (Siqueiros Beltrones and López Fuerte 2003). Fresh material was observed in fresh mounts to observe the approximate proportion of empty frustules (dead) and live cells at the time of sampling. The root segments were then brushed using a toothbrush and rinsed with tap water to obtain a concentrate of sediments, organic matter, and diatoms. The organic matter inside (and outside) diatom frustules was oxidized using a 1:3:1 mixture of sample, nitric acid, and commercial ethanol (Siqueiros Beltrones 2000). The clean frustules were mounted using plastic resin mounting medium (Meltmount) (refractive index $=1.7$ ), yielding three permanent slides from each composite sample.

The floristic analysis was carried out separately from the quantitative analysis to identify as many taxa as possible in the assemblages. Drawings were made of the observed taxa on curatorial cards, which included information on site location, habitat, frequency, and morphometric data. These were delivered, along with all 36 slides, to the Museo de Historia Natural of the Universidad Autónoma de Baja California Sur, to be deposited eventually in the diatom collection (Diatomario). As a floristic reference, color microphotographs were taken (with Kodak 800 film) of selected taxa (including new records) from the permanent slides under an Olympus $\mathrm{CH}-2$ microscope using phase-contrast illumination.

Taxonomic determinations were accom- plished following the works of Schmidt et al. (1874-1959), Peragallo and Peragallo (18971908), Hustedt (1927-1966, 1955), CleveEuler (1951-1955), Hendey (1964), McIntire and Reimer (1974), Foged (1975, 1984), Reyes-Vázquez (1975), Navarro (1982), Siqueiros Beltrones and Ibarra-Obando (1985), Simonsen (1987), Moreno et al. (1996), Round and Bukhtiyarova (1996), Siqueiros Beltrones and Morzaria Luna (1999), Siqueiros Beltrones and Sánchez Castrejón (1999), Witkowski et al. (2000), and Siqueiros Beltrones (2000, 2002). The classification of Round et al. (1990) was followed.

\section{Assemblage Structure}

To determine the relative abundances of the diatom taxa, a sample size of 500 individuals (frustules) per slide was chosen based on McIntire and Overton (1971) and Siqueiros Beltrones (1990). Numerical analyses were done twice (using subsamples) based on two slides from the same sample.

To estimate species diversity in the assemblages, information theory $\left(\log _{2}\right)$ was used (Shannon and Weaver 1949). Values for Shannon's $\mathrm{H}^{\prime}$, Pielou's evenness $\left(\mathrm{J}^{\prime}\right)$, and dominance using the redundancy index (REDI) were computed (Brower and Zar 1984). Simpson's diversity index $(1-\lambda)$ was also calculated (Brower and Zar 1984), to better interpret our estimates of diversity by considering criteria that weight rare and common species differently (Siqueiros Beltrones 1990).

Under the premise that all sites represented the same type of habitat, and thus harbored diatom assemblages with similar structure, statistical analyses were carried out. A two-way analysis of variance (ANOVA) was applied to test for $\mathrm{H}_{0}=$ no significant differences existed between the diversity values due to level of exposure and/or date of sampling $(\alpha=0.05)$. This was done only for the estimated values of the diversity indices $\left(\mathrm{H}^{\prime}, \mathrm{J}^{\prime}\right.$, and REDI), because normality (Shapiro-Wilk test) and homoscedasticity (Cochran test) tested positive (SAS Institute 2001). Other requirements were also met to comply with the use of parametric statistics. The observed values for Simpson's diversity and domi- 
nance did not show a normal distribution and thus were not considered in the statistical analyses.

To measure similarity among diatom assemblages, samples were compared on the basis of presence/absence of species and their relative abundances using Horn's Index (Magurran 1988). These values were fed into an algomerative classification module of a flexible algorithm for the construction of dendrograms (de la Cruz-Agüero 1994). Because no difference existed in the resulting classification when using both sample and subsample values or just sample values, only the latter were represented.

A principal component (ordination) analysis (PCA) was used to determine grouping tendencies between species. A mode $\mathrm{R}$ matrix was selected for running the eigen-analysis of a variance-covariance matrix (de la CruzAgüero 1994). Only 50 species representing $85 \%$ of the total frustule count (including subsamples) were considered for the PCA computation.

Finally, to determine the dominant species based on abundance and frequency, the Biological Value Index (BVI) or species importance was estimated for 40 of the taxa with higher scores in the PCA. The BVI was computed by assigning a decreasing rank value (from 40 to 1 ), according to their descending abundances, to the taxa from each sample and adding up their overall rank values to give a BVI value for each taxon (Sanders 1960).

\section{RESULTS}

The floristic analysis of epiphytic diatoms living on Rhizophora mangle prop roots during November and April yielded a total of 171 taxa (species and their varieties) representing 49 genera. The number of dead (empty) cells was negligible. Sixteen species were new records for the NW Mexican region (Appendix), but none of these was numerically important. Other taxa, although not abundant, appear to be representative of the assemblages (i.e., large forms that occurred frequently, such as Amphora clevei, Campylodiscus samoensis, Diploneis crabro, Diploneis obliqua,
Lyrella exsula, Lyrella irrorata, Oestrupia powellii var. vidovichii, Petroneis granulata, Surirella fastuosa var. suborbicularis, Trachyneis velata, and Triceratium favus [Figures 2-12]).

In the quantitative analysis, a total of 12,422 frustules was counted in 24 subsamples, which accounted for 147 taxa. All the samples (and their repetitions) were characterized by high species richness, with $\mathrm{S}$ ranging from 56 taxa in the lower-level (LL) sample Z3-LL-00 to 90 taxa in sample Z1LL-99 (Table 1); both samples were from the lower level of the prop roots. No clear tendency was evident for whether a higher number of taxa occurred in the lower or upper level of exposure.

Diversity values showed a tendency for being higher in the assemblages collected from the lower level of the prop roots. Evenness measurements were high, with a mean $\mathrm{J}^{\prime}$ value of 0.790 . This indicates that there was also a somewhat homogeneous distribution of individuals among species with no single taxon being clearly dominant (Table 1). This is also reflected in high mean estimates of diversity using two indices $\left(\mathrm{H}^{\prime}=4.89\right.$ and $1-\lambda=0.945)$ and a corresponding low mean value of dominance (REDI). The lowest diversity measured $\left(\mathrm{H}^{\prime}=4.35\right.$ and $1-\lambda=$ $0.925)$ corresponded with the lowest $S$ but with a $\mathrm{J}^{\prime}=0.75$, and the highest diversity was $\mathrm{H}^{\prime}=5.2$ and $1-\lambda=0.963$, which corresponded to the highest $\mathrm{S}$ and a $\mathrm{J}^{\prime}=0.804$. The highest $\mathrm{J}^{\prime}$ (0.832) corresponded with $\mathrm{H}^{\prime}=5.19$ and $\mathrm{S}=76$. The number of taxa per sample appeared to be the main component of the high diversity values estimated, although the distribution of individuals among the taxa was also fairly even.

Although tendencies may be noted in the diversity values due to level of exposure, with values of diversity being higher in the lowerlevel diatom assemblages, only the REDI values (of dominance) were found to be significantly different in the two-way ANOVA, albeit from date to date but not for level of exposure or due to interaction $(\alpha=0.05)$. Moreover, the diversity values $\left(\mathrm{H}^{\prime}\right.$ and $\left.\mathrm{J}^{\prime}\right)$ were not significantly different in any case. Because all indices are derived from information theory, they are considered comple- 

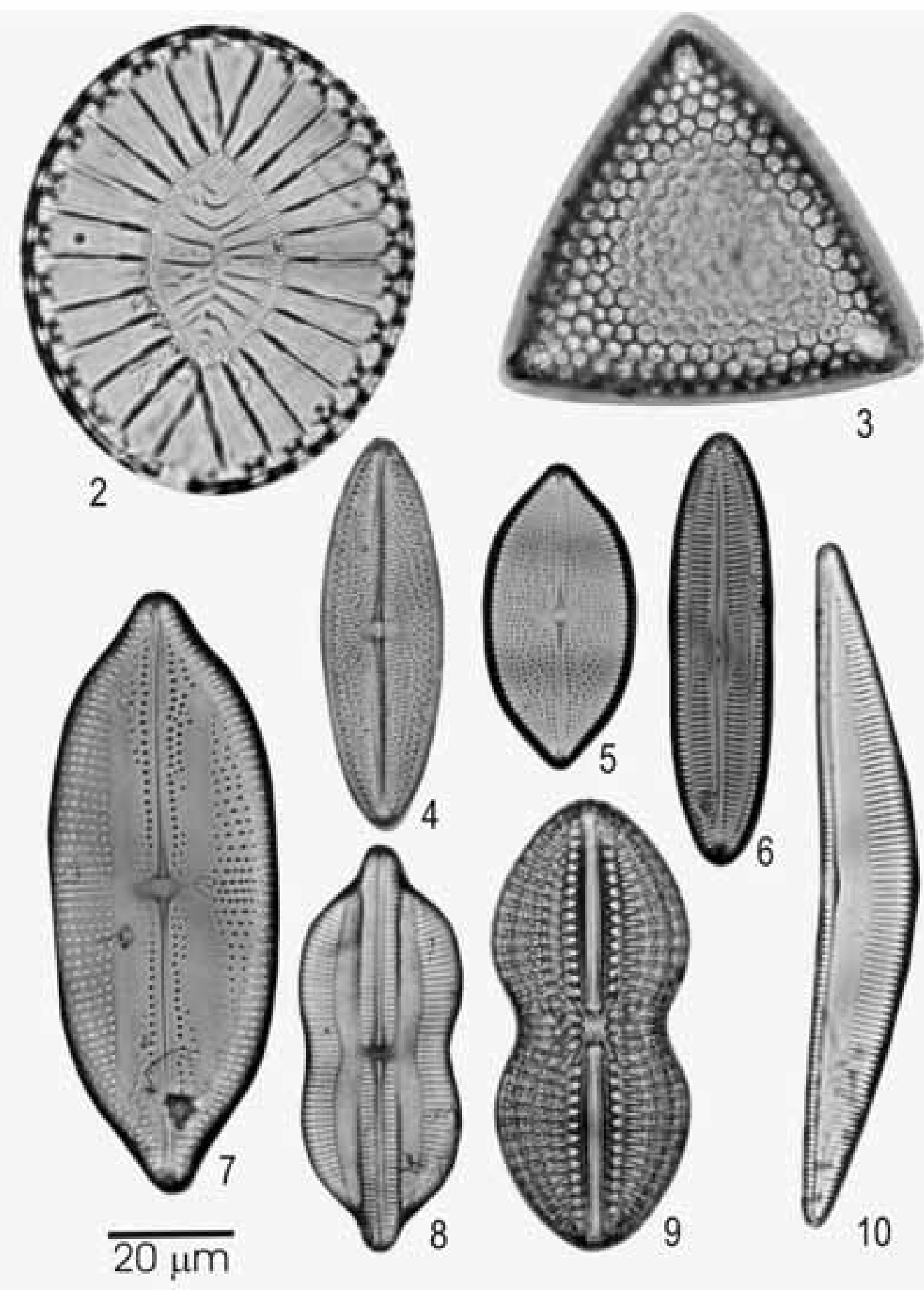

Figures 2-12. Common benthic diatom taxa considered representative of the mangrove prop root system. 2, Surirella fastuosa var. suborbicularis Grunow; 3, Triceratium favus Ehrenberg; 4, Trachyneis velata A. Schmidt; 5, Petroneis granulata (Bailey) D. G. Mann; 6, Lyrella irrorata (Greville) Mann; 7, Lyrella exsula (A. Schmidt) D. G. Mann; 8, Diploneis crabro Ehrenberg; 9, Amphora clevei Grunow; 10, Oestrupia powellii var. vidovichii (Gregory) Heiden; 11, Diploneis obliqua (Brun) Hustedt; 12, Campylodiscus samoensis Grunow. 


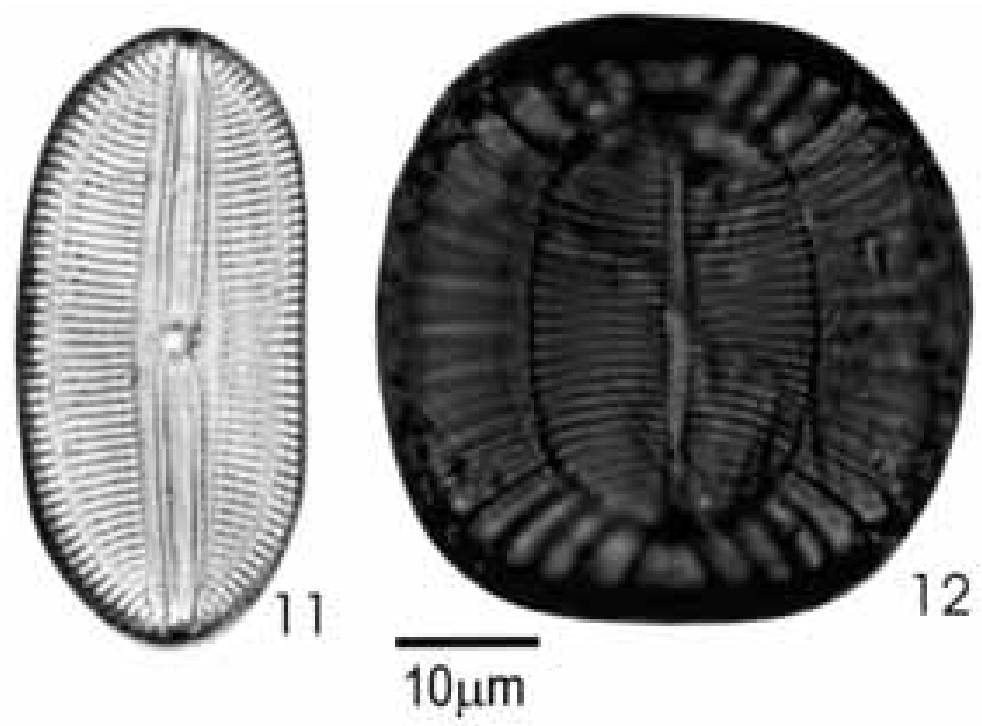

Figures 2-12. (continued)

mentary in describing the structure of the assemblages. A marked variation can be noted among the diversity values and between their repetitions, so it is likely that the REDI differences are due to chance. Thus, we cannot reject our $\mathrm{H}_{0}$, and the measured parameters are proposed to represent similar assemblages, albeit with a high variability.

The similarity analysis using Horn's Index produced a grouping by month, with high similarity values, as it considers species relative abundances in the comparisons. It also grouped the assemblages by level of exposure (Figure 13). Several abundant species caused the definition of the three groups (Figure 13). The most abundant ones include Group A, Diadesmis cf. contenta, Navicula platyventris, and Catacombas gaillonii; Group B, Nitzschia sp. 1, Acbnanthidium sp. 1, and Acbnanthes suchlandtii; Group C, Navicula salinarum, Amphora salina var. tenuissima, $A$. costata, and $A$. bigibba. However, Horn's similarity index also indicates that other abundant or common species are evenly distributed among the sampling sites (those with the higher BVI values), which may be considered to have the same salinity and desiccation conditions in general, including both levels of exposure. The whole habitat may be considered some- what hypersaline even with the relatively cooler air temperatures in November and April (Table 2).

In the PCA two main components or factors explained $56 \%$ of the total variance. These were constructed on the basis of higher abundances in the April upper-level samples, which is reflected in Axis I; the November samples gave rise to Axis II. The higher scores (i.e., the degree to which the taxa are related to the factor [component] either positive or negative) corresponded to 12 of the most abundant species (Nitzschia frustulum, Gomphonemopsis pseudexigua, Achnanthes yaquinensis, Diadesmis cf. contenta, Catacombas gaillonii, Amphora salina var. tenuissima, Achnanthidium sp. 1, Nitzschia amphibia, Nitzschia dissipata, Navicula salinarum, Amphora bigibba, Nitzschia sp. 1) (Figures 14-26), which appear quasi-isolated in the resulting diagram (Figure 27). Most of the remaining taxa had low scores and were grouped closely around the center. The PCA coincides with the fact that, although the similarity analysis yielded three groups, these were still closely related at a similarity (Horn) value of 0.705 versus a maximum computed value of 0.888 (Figure 13). This indicates that throughout the sampling sites and exposure levels species are 
TABLE 1

Diversity Values Used to Describe the Structure of the Diatom Assemblages Found on Red Mangrove (Rhizophora mangle) Prop Roots in November 1999 (99) and April 2000 (00) in Bahía Magdalena, B.C.S.

\begin{tabular}{|c|c|c|c|c|c|c|}
\hline Sample $a$ & $n$ & $\mathrm{~S}$ & $\mathrm{H}^{\prime}$ & $\mathrm{J}^{\prime}$ & $1-\lambda$ & REDI \\
\hline \multicolumn{7}{|l|}{ November } \\
\hline Z1-UL-99 & 504 & 61 & 4.50 & 0.761 & 0.931 & 0.303 \\
\hline Z1-UL-99-R & 504 & 63 & 4.40 & 0.737 & 0.923 & 0.333 \\
\hline Z1-LL-99 & 553 & 90 & 5.20 & 0.804 & 0.961 & 0.26 \\
\hline Z1-LL-99-R & 556 & 76 & 4.75 & 0.761 & 0.943 & 0.309 \\
\hline Z2-UL-99 & 519 & 76 & 4.90 & 0.786 & 0.947 & 0.281 \\
\hline Z2-UL-99-R & 518 & 81 & 4.86 & 0.767 & 0.942 & 0.310 \\
\hline Z2-LL-99 & 509 & 75 & 4.59 & 0.741 & 0.929 & 0.342 \\
\hline Z2-LL-99-R & 506 & 70 & 5.03 & 0.824 & 0.953 & 0.22 \\
\hline \multicolumn{7}{|l|}{ April } \\
\hline Z1-UL-00 & 502 & 61 & 4.90 & 0.827 & 0.955 & 0.219 \\
\hline Z1-UL-00-R & 545 & 66 & 4.89 & 0.811 & 0.954 & 0.238 \\
\hline Z1-LL-00 & 537 & 81 & 5.17 & 0.819 & 0.962 & 0.24 \\
\hline Z1-LL-00-R & 542 & 78 & 5.15 & 0.823 & 0.963 & 0.232 \\
\hline Z2-UL-00 & 495 & 65 & 4.94 & 0.821 & 0.954 & 0.229 \\
\hline Z2-UL-00-R & 504 & 58 & 4.46 & 0.762 & 0.931 & 0.296 \\
\hline Z2-LL-00 & 508 & 72 & 5.05 & 0.819 & 0.955 & 0.23 \\
\hline Z2-LL-00-R & 530 & 76 & 5.19 & 0.832 & 0.956 & $0.21 \xi$ \\
\hline Z3-UL-00 & 511 & 75 & 4.84 & 0.777 & 0.936 & 0.292 \\
\hline Z3-UL-00-R & 498 & 82 & 5.15 & 0.811 & 0.956 & 0.256 \\
\hline Z3-LL-00 & 501 & 56 & 4.35 & 0.751 & 0.925 & 0.31 \\
\hline Z3-LL-00-R & 526 & 68 & 4.62 & 0.761 & 0.937 & 0.30 \\
\hline Z4-UL-00 & 515 & 70 & 4.82 & 0.787 & 0.949 & 0.27 \\
\hline Z4-UL-00-R & 506 & 66 & 4.47 & 0.741 & 0.926 & 0.333 \\
\hline Z4-LL-00 & 505 & 67 & 4.94 & 0.816 & 0.952 & 0.236 \\
\hline Z4-LL-00-R & 525 & 72 & 5.16 & 0.841 & 0.962 & \\
\hline Mean & & & 4.89 & 0.790 & 0.945 & 0.27 \\
\hline UL Mean & & & 4.76 & 0.782 & 0.942 & 0.280 \\
\hline LL Mean & & & 4.93 & 0.799 & 0.948 & 0.260 \\
\hline
\end{tabular}

Note: $n$, sample size (frustules); $\mathrm{S}$, number of species; $\mathrm{H}^{\prime}$ Shannon's diversity index; $\mathrm{J}^{\prime}$, evenness; $1-\lambda$, Simpson diversity index; REDI, redundancy.

${ }^{a} \mathrm{Z}$, site; UL, dry (upper level); LL, damp (lower level); R, repetition (subsample).

more or less evenly (or randomly for rare taxa) distributed. Although no significant differences were detected (two-way ANOVA) in the diversity values of the assemblages $(\alpha=0.05)$, thus supporting the acceptance of the $\mathrm{H}_{0}$ (no significant differences existed between the diversity values due to level of exposure and/or date of sampling), temporal differences do exist in the distribution of taxa, including abundant species, depicted by the PCA (i.e., similar species richness and diversity but somewhat different species composition).
The BVI values computed for the 40 most abundant taxa comprising $85 \%$ of the total frustule count are shown in Table 3 . These taxa are responsible for most of the similarity between the epiphytic diatom assemblages and their seasonal separation because of their abundance and frequency in the samples. Around $50 \%$ of these taxa have in fact been recorded as typical epiphytes, either on sea grasses, macroalgae, or mangroves (e.g., $A$. yaquinensis, A. bigibba, C. gaillonii, C. scutellum, Diadesmis cf. contenta, G. pseudexigua, N. frustulum, O. pacifica, and T. tabulata var. affinis, among others), and the rest have been observed to occur in sediments as epipelic or epipsammic forms.

\section{DISCUSSION}

This study gives a first insight into the structure of diatom assemblages found on mangrove prop roots from the Bahía Magdalena lagoon system during the cool season. This floristic inventory for benthic diatoms (171 taxa) is the smallest one recorded for the Baja California peninsula, where epipelic, epilithic, and epiphytic assemblages have been analyzed, both in the northern and southern parts of the peninsula (Siqueiros Beltrones 2002). Studies elsewhere on mangrove roots by Sullivan (1981), Maples (1983), and $\mathrm{Na}-$ varro and Torres (1987) yielded an even smaller number of diatom taxa: 83, 23, and 107, respectively. Navarro (1982), on the other hand, recorded 226 taxa in 234 samples during a year cycle.

Much floristic work is yet to be done in the NW Mexican region. However, many diatom species previously have been recorded from sediments in mangrove systems farther south in the Sea of Cortés (Siqueiros Beltrones and Morzaria Luna 1999, Siqueiros Beltrones and Sánchez Castrejón 1999). Most are common epipelic forms that can easily be suspended as tychoplankton, which may eventually settle down on the prop roots where sediments also accumulate. System dynamics in Bahía Magdalena are determined by tidal ebb and flow (Acosta-Ruíz and Lara-Lara 1978) that resuspend benthic diatoms from different substrates, which are eventually transported 


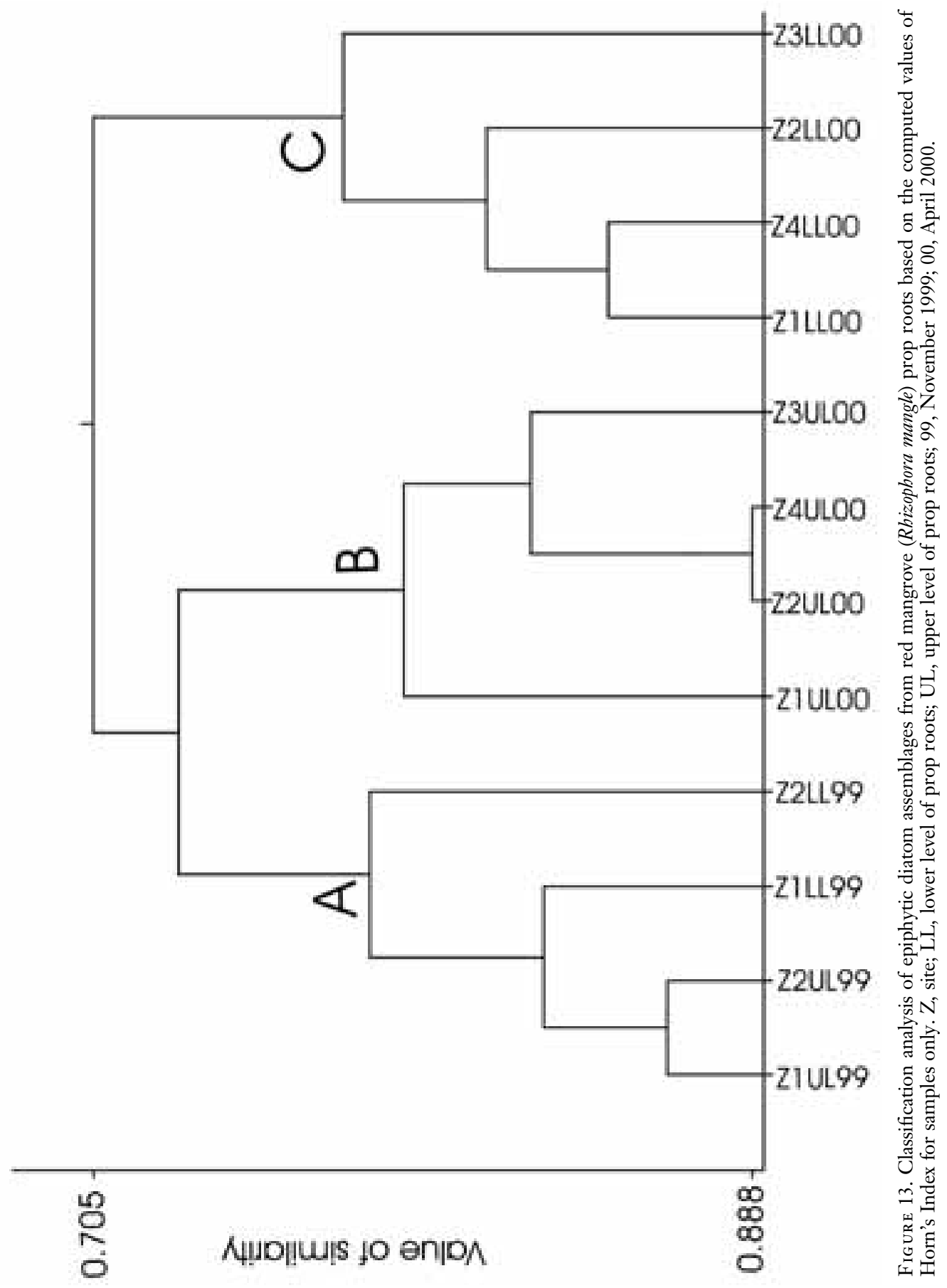


TABLE 2

Mean Sediment Salinity (psu) and Air Temperature $\left({ }^{\circ} \mathrm{C}\right)$ Measurements for the Sampling Dates at Bahía Magdalena

\begin{tabular}{lcclcc}
\hline \hline Date & Z-1 & Z-2 & Z-3 & Z-4 & Temperature \\
\hline Nov. 1999 & 44 & 43 & NM & NM & 22 \\
April 2000 & 45 & 41 & 40 & 45 & 25 \\
\hline
\end{tabular}

Note: Z, sampling site; NM, no measurement.

toward the Pacific Ocean. Many tychoplanktonic species of diatoms have been collected $200 \mathrm{~km}$ NW of Bahía Magdalena at 300-m depth (Martínez López et al. 2004). A more complete knowledge of the species composition and assemblage structure of benthic diatoms in the system will provide the basis for studies on their geographical distribution and for tracing certain oceanographic events in the area.

Many more species are expected to be found inside Bahía Magdalena when more extensive surveys get under way that consider other types of substrates. The new records of species include both epipelic and epiphytic forms found on macroalgae, and only $A c h-$ nanthes suchlandtii (Figure 26) had a high BVI value (i.e., it was abundant and frequent in several samples). These new records along with other taxa that were not numerically important may prove more abundant in other habitats of the bay (e.g., A. sucblandtii, along with Diadesmis cf. contenta [also with a high BVI]). Although typical of freshwater environments, the latter taxon also occurs commonly in marine habitats (Navarro 1982). Our specimen of $D$. contenta closely resembles that of Navarro (pl. 30, figs. 1-3, as Navicula contenta), who stated its sublittoral distribution in warm-temperate waters. And, although no marine records for $A$. suchlandtii were found, our specimen closely resembles those in Schmidt et al. (1874-1959) and Hustedt (1927-1966), albeit Bahía Magdalena is considered an antiestuary (Guerrero et al. 1988) with low freshwater input. However, in other surveys of the region many freshwater taxa have been recorded from similar marine habitats (Siqueiros Beltrones 2002).
Differences in sediments may cause differences in the diatom assemblages (e.g., no Mastogloia [G. H. K. Thwaites] species were recorded in this study, but current observations by the authors are revealing a high abundance and variety of conspicuous Mastogloia species in sediments of Bahía Magdalena in other localities although not in this one). And, indeed Mastogloia and Lyrella species appear to be distinctive in the benthic diatom assemblages in Bahía Magdalena (López Fuerte 2004), which are distributed according to Witkowski et al.'s (2000) oases or hot spots (i.e., either absent or abundant).

The epiphytic diatom assemblages found on $R$. mangle prop roots of Bahía Magdalena are apparently similar to many other benthic diatom assemblages, having few abundant specific taxa and many rare or uncommon species. However, the species diversity $\left(\mathrm{H}^{\prime}\right)$ values estimated here are the highest recorded in similar studies for benthic diatoms in other mangrove systems (Sullivan 1981, Navarro 1987, Siqueiros Beltrones and Sánchez Castrejón 1999). Although the high number of species per sample does influence these estimates, $\mathrm{J}^{\prime}$ and $\lambda$ values were also higher than in other coastal environments with a high primary production (listed by Siqueiros Beltrones 1998, 2002).

Those studies were focused on diatom assemblages from well-defined substrates (sea grasses, macroalgae, and different type of sediments), whereas the specific substrate for the diatoms found on the prop roots of $R$. mangle was not well discriminated. It is evident that these diatom assemblages are part of a well-defined habitat composed of the prop roots, attached sediments, and macroalgae, all subject to high salinities and desiccation pressures. However, the high diversity of the diatom assemblages in this particular habitat suggests that salinity and desiccation conditions cannot be considered extreme, and according to Pielou (1975) a certain stability exists.

In summary, the diatom assemblages found on prop roots of $R$. mangle are characterized by a high species diversity that is similar in both levels of exposure (desiccation) and sampling dates representing the cool season. 


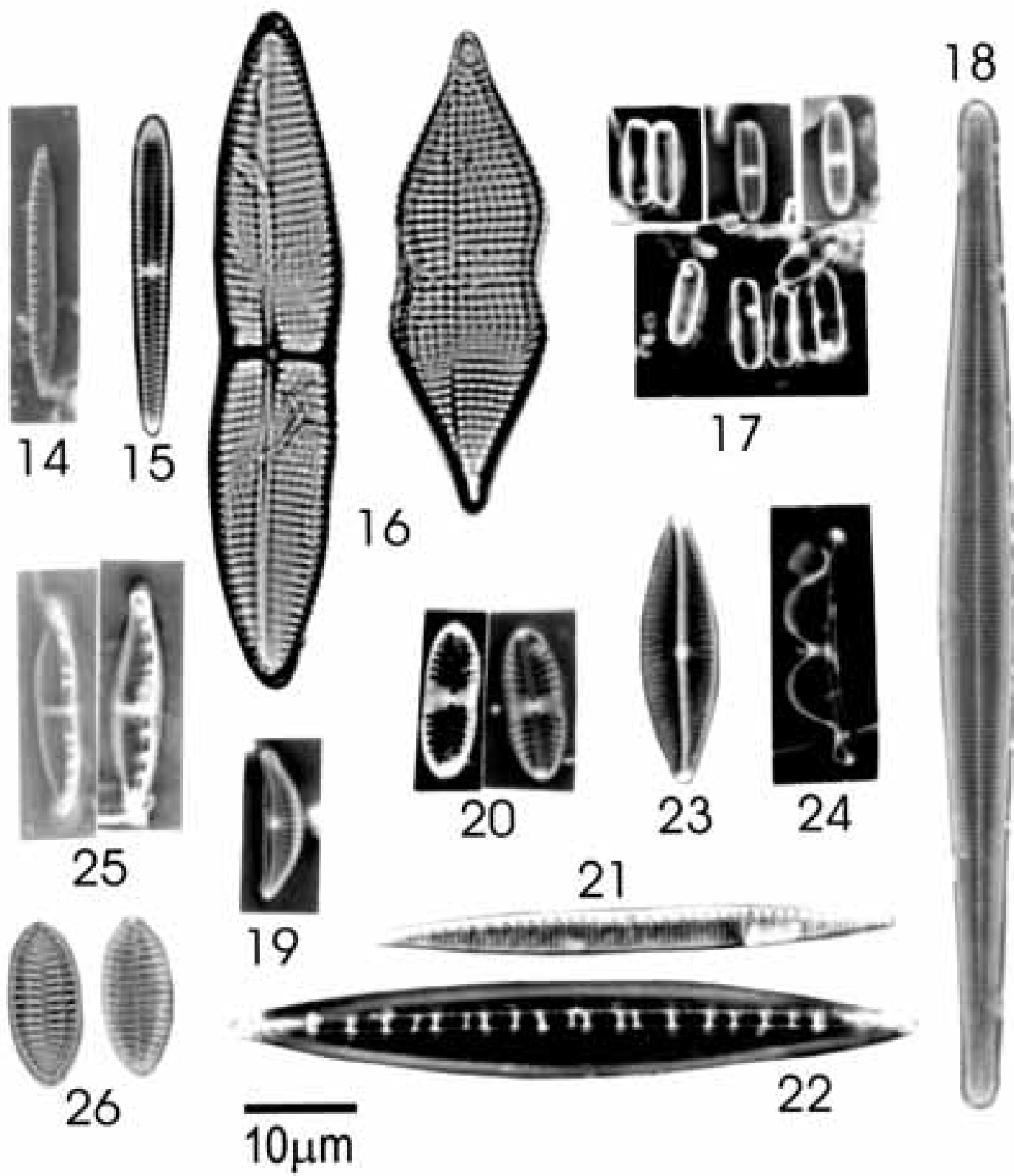

Figures 14-26. Taxa (abundant) showing the highest scores with the first two factors computed in the PCA: 14, Nitzschia frustulum var. frustulum (Kützing) Grunow; 15, Gomphonemopsis pseudexigua (Simonsen) Medlin; 16, Achnanthes yaquinensis McIntire \& Reimer; 17, Diadesmis cf. contenta Grunow; 18, Catacombas gaillonii (Bory) Williams \& Round; 19, Amphora salina var. tenuissima Hustedt; 20, Acbnanthidium sp. 1; 21, Nitzschia amphibia Grunow; 22, Nitzschia dissipata (Kützing) Grunow; 23, Amphora bigibba Grunow; 24, Navicula salinarum Grunow; 25, Nitzschia sp. 1; 26, Achnanthes suchlandtii Hustedt. 


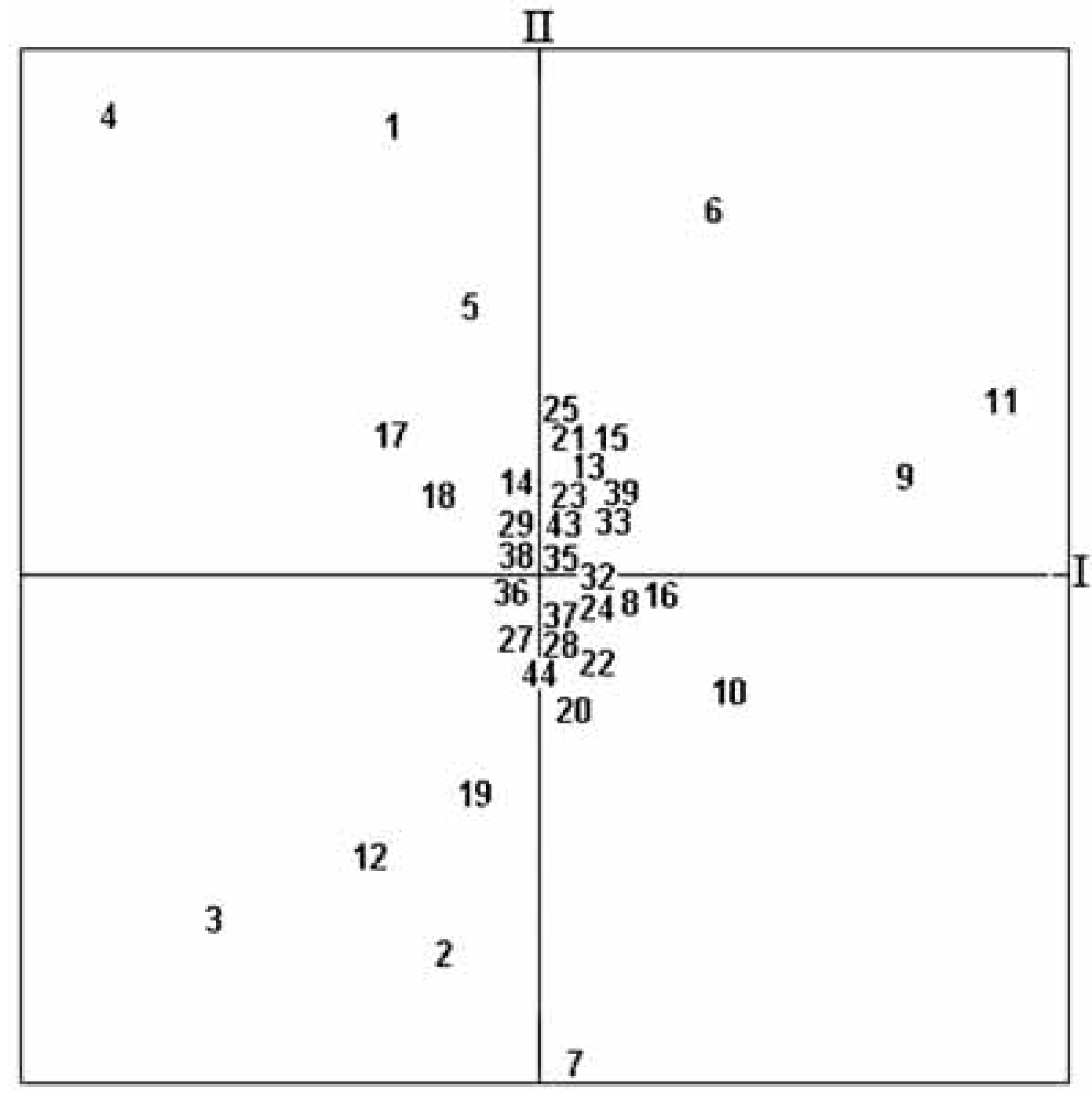

Figure 27. Distribution of PCA scores for 50 species of epiphytic diatoms from red mangrove (Rhizophora mangle) prop roots. Numbers not shown were concentrated in the center of the diagram. 1, Nitzschia frustulum; 2, Gomphonemopsis pseudexigua; 3, Achnanthes yaquinensis; 4, Diadesmis cf. contenta; 5, Catacombas gaillonii; 6, Amphora salina var. tenuissima; 7, Achnanthidium sp. 1; 8, Nitzschia amphibia; 9, Nitzschia dissipata; 10, Navicula salinarum; 11, Amphora bigibba; 12, Nitzschia sp. 1; 13, Nitzschia frustulum var. perminuta; 14, Opephora pacifica; 15, Navicula platyventris; 16, Amphora costata; 17, Navicula pennata; 18, Nitzschia denticula; 19, Achnanthes suchlandtii; 20, Nitzschia brittoni; 21, Navicula parva; 22, Achnanthes brevipes var. intermedia; 23, Amphora acutiuscula; 24, Seminavis sp. 1; 25, Psammodyction constrictum; 26, Nitzschia grossestriata; 27, Planothidium hauckianum; 28, Achnanthes kuwaitensis cf. parvula; 29, Cocconeis scutellum; 30, Achnanthes brevipes var. parvula; 31, Paralia sulcata var. radiata; 32, Tabularia tabulata var. affinis; 33, Nitzschia angularis; 34, Paralia sulcata; 35, Amphora coffeaeformis var. salina; 36, Catenula adhaerens; 37, Cyclotella striata; 38, Navicula agnita; 39, Hyalosynedra laevigata; 40, Thalassionema nitzschioides; 41, Trachyneis velata; 42, Tryblionella acuminata; 43, Nitzschia lanceolata var. minor; 44, Achnanthidium minutissima; 45, Cocconeis scutellum var. parva; 46, Cocconeis placentula; 47, Cyclotella litoralis; 48, Cocconeis diminuta; 49, Cocconeis dirupta; 50, Lyrella clavata var. subconstricta. 
TABLE 3

Biological Value Index (BVI) Estimates for the 40 Species That Comprised $\approx 85 \%$ of the Total Frustule Count in the 24 Subsamples

\begin{tabular}{|c|c|c|}
\hline \multicolumn{2}{|l|}{ Species } & \multirow{2}{*}{$\frac{\text { BVI }}{156}$} \\
\hline Achnanthes brevipes var. intermedia & $\mathrm{E}^{a}$ & \\
\hline Achnanthes brevipes var. parvula & $\mathrm{E}$ & 112 \\
\hline Achnanthes cf. kuwaitensis paroula & $\mathrm{E}$ & 137 \\
\hline Achnanthes suchlandtii & & 148 \\
\hline Achnanthes yaquinensis & $\mathrm{E}$ & 508 \\
\hline Achnantbidium minutissima & $\mathrm{E}$ & 66 \\
\hline Achnantbidium sp. 1 & $\mathrm{E}$ & 255 \\
\hline Amphora acutiuscula & & 107 \\
\hline Amphora bigibba & $\mathrm{E}$ & 228 \\
\hline Amphora coffeaeformis var. salina & & 85 \\
\hline Amphora costata & & 261 \\
\hline Amphora salina var. tenuissima & $\mathrm{E}$ & 370 \\
\hline Catacombas gaillonii & $\mathrm{E}$ & 416 \\
\hline Catenula adhaerens & & 96 \\
\hline Cocconeis scutellum & $\mathrm{E}$ & 132 \\
\hline Cyclotella striata & & 105 \\
\hline Diadesmis cf. contenta & $\mathrm{E}$ & 296 \\
\hline Gomphonemopsis pseudexigua & $\mathrm{E}$ & 591 \\
\hline Navicula agnita & & 92 \\
\hline Navicula parva & & 170 \\
\hline Navicula pennata & & 161 \\
\hline Navicula platyventris & & 228 \\
\hline Navicula salinarum & & 327 \\
\hline Nitzschia amphibia & $\mathrm{E}$ & 397 \\
\hline Nitzschia angularis & & 126 \\
\hline Nitzschia brittonii & & 155 \\
\hline Nitzschia denticula & & 193 \\
\hline Nitzschia dissipata & $\mathrm{E}$ & 261 \\
\hline Nitzschia frustulum var. frustulum & $\mathrm{E}$ & 553 \\
\hline Nitzschia frustulum var. perminuta & $\mathrm{E}$ & 355 \\
\hline Nitzschia grossestriata & & 137 \\
\hline Nitzschia sp. 1 & & 243 \\
\hline Opephora pacifica & $\mathrm{E}$ & 285 \\
\hline Paralia sulcata & $\mathrm{E}$ & 62 \\
\hline Paralia sulcata var. radiata & $\mathrm{E}$ & 94 \\
\hline Planotbidium bauckianum & & 152 \\
\hline Psammodyction constrictum & & 112 \\
\hline Seminavis sp. 1 & $\mathrm{E}$ & 150 \\
\hline Tabularia tabulata var. affinis & $\mathrm{E}$ & 122 \\
\hline Trachyneis velata & $\mathrm{E}$ & 62 \\
\hline
\end{tabular}

${ }^{a} \mathrm{E}$, commonly recorded as epiphyte.

However, the taxa composing the assemblages may differ according to level of exposure and date. Thus, based on the structure of the diatom assemblages (species diversity and its components), it is concluded that all the sampling sites represent a similar habitat, and in spite of the similar salinity and temperature the November and April assemblages could be discriminated in the analysis due to the differential distribution of taxa.

The distribution of epiphytic macroalgae on the prop roots of $R$. mangle depends on the different physiological response to desiccation stress and photosynthetic recovery capacity of the specific taxon (Peña et al. 1999). This may well be expected to occur in diatoms distributed in different levels of exposure. Thus, the observed variations may represent this type of physiological adaptation, but during warmer months other strategies may be detected.

In the warm period air temperatures easily surpass $35^{\circ} \mathrm{C}$, and water temperatures range from $20^{\circ} \mathrm{C}$ in April to $28^{\circ} \mathrm{C}$ in September (Gárate-Lizárraga and Siqueiros Beltrones 1998). Cool and warm seasons are clearly defined in this area and are associated with a high and low species diversity in phytoplankton assemblages, respectively (Gárate Lizárraga et al. 2000, 2001). This same effect may characterize the epiphytic diatom assemblages on red mangrove prop roots. Epiphytic diatom assemblages during the warm period are thus hypothesized to be quite different from the surveyed assemblages of the cool season, exhibiting strategies more suitable to more extreme conditions. Also, because different diatom species are found on different species of macroalgae (McIntire and Moore 1977, Main and McIntire 1974, Tanaka 1986, Tanaka and Asakawa 1986, Siqueiros Beltrones 2002, Siqueiros Beltrones and López Fuerte 2003) the structure of the diatom assemblages in the epiphytic macroalgae occurring on the prop roots is also expected to vary, mainly rhodophytes and chlorophytes on which dense growths of diatoms have been observed (Siqueiros Beltrones and López Fuerte 2003). These may contribute to the diatom diversity in any given habitat. In our study site the red alga Spyridia filamentosa (Wulfen) Harvey is common throughout the year (Sánchez Rodríguez et al. 1989). However, many of the diatom taxa in this study were better represented on macroalgae separated from the root segments: Ulva sp. (chlorophyte), and the red alga Polysiphonia sp. and a species of the Gelidiales that 
were densely covered by diatoms (Siqueiros Beltrones and López Fuerte 2003).

Bahía Magdalena represents the northern limit of mangrove systems (Blasco 1984) and many species of macroalgae (Dawson 1960, Riosmena Rodríguez and Siqueiros Beltrones 1996). The effects of the transitional nature of the study area have been observed on the phytoplankton assemblages inside the bay, where temperate and tropical species cooccur. Complex oceanographic conditions in this area may explain the high diversity of diatoms in mangrove prop root assemblages. Their biogeographical affinities reflect the influence of temperate and warm waters (Gárate Lizárraga and Siqueiros Beltrones 1998, Gárate Lizárraga et al. 2001) most likely related to the California and Costa Rica Currents. However, to determine the similarity between this and other mangrove systems in the NW Mexican region, it is necessary to compare both floristics and assemblage structure of the benthic diatoms occurring in the different substrates.

\section{ACKNOWLEDGMENTS}

We thank Mike Sullivan and two anonymous reviewers whose observations helped to make this a much better paper. Oscar Hernández Almeida edited the diatom plates.

\section{Literature Cited}

Acosta-Ruíz, M., and J. R. Lara-Lara. 1978. Resultados fisicoquímicos en un estudio de variación diurna en el área central de Bahía Magdalena, B.C.S. Cienc. Mar. 5 (1): 3746.

Alvarez-Borrego, S., L. A. Galindo-Bect, and A. Chee-Barragán. 1975. Características hidroquímicas de Bahía Magdalena, B.C.S. Cienc. Mar. 2 (2): 94-109.

Blasco, F. 1984. Climatic factors and the biology of mangrove plants. Pages 18-35 in S. Snedaker and J. Snedaker, eds. The mangrove ecosystem: Research methods. UNESCO/SCOR, Paris.

Brower, J. E., and J. H. Zar. 1984. Field and laboratory methods for general ecology. Wm. C. Brown Co., Dubuque, Iowa.
Cahoon, L. B., and K. A. Safi. 2002. Distribution and biomass of benthic microalgae in Manukau Harbor, New Zealand. N. Z. J. Mar. Freshwater Res. 36:257-266.

Cleve-Euler, A. 1951-1955. Die Diatomeen von Schweden un Finnland. I-V. K. Sven. VetenskapsAkad. Handl. Ser. 4, 2 (1): 1163 (1951); Ser. 4, 3 (3): 1-153 (1952); Ser. 4, 4 (2): 1-158 (1953); Ser. 4, 4 (5): 1-255 (1953); Ser. 4, 5 (4): 1-232 (1955).

Dawson, E. Y. 1960. The biogeography of Baja California and adjacent seas. Part II. Marine biotas: A review of the ecology, distributions, and affinities of the benthic flora. Syst. Zool. 9 (3-4): 93-100.

de la Cruz-Agüero, G. 1994. Sistema de análisis de comunidades. Versión 3.0. Departamento de Pesquerías y Biología Marina. Centro Interdisciplinario de Ciencias del Mar-Instituto Politécnico Nacional, La Paz, B.C.S., México.

Foged, N. 1975. Some littoral diatoms from the coast of Tanzania. Bibl. Phycol. 16:1123.

- 1984. Freshwater and littoral diatoms from Cuba. Bibl. Diatomol. 5:1-243.

Gárate-Lizárraga, I., and D. A. Siqueiros Beltrones. 1998. Time variation in phytoplankton assemblages in a subtropical lagoon system after the 1982-1983 "El Niño" event (1984 to 1986). Pac. Sci. 52:79-97.

Gárate-Lizárraga, I., and G. Verdugo Díaz. 2001. Checklist of marine phytoplankton in a subtropical lagoon system in Baja California Sur, México, from 1980 to 1989. Pages 255-270 in B. S. Rushton, P. Hackney, and C. R. Tyrie, eds. Biological collections and biodiversity. Linnean Society Occasional Publications. Westbury Publishing, U.K.

Gárate-Lizárraga, I., D. A. Siqueiros Beltrones, G. Verdugo, and R. Guerrero. 2000. Dinámica del fitoplancton en el sistema lagunar Magdalena-Almejas. Pages 143-155 in D. Lluch Belda, J. Elorduy Garay, S. Lluch Cota, and G. Ponce Díaz, eds. BAC: Centros de actividad biológica del Pacífico mexicano. Centro de Investigaciones Biológicas del Noroeste, Centro Interdisciplinario de Ciencias del Mar, 
Consejo Nacional de Ciencia y Tecnología, La Paz, B.C.S., México.

Gárate-Lizárraga, I., G. Verdugo Díaz, and D. A. Siqueiros Beltrones. 2001. Variations in phytoplankton assemblages under normal and anomalous conditions in a subtropical lagoon system on the west coast of México. Oceánides 16 (1): 1-16.

Guerrero, R., R. Cervantes Duarte, and A. Jiménez Illescas. 1988. Nutrient variation during a tidal cycle at the mouth of a coastal lagoon in the northwest of México. Indian J. Mar. Sci. 3:235-237.

Hendey, N. I. 1964. An introductory account of the smaller algae of British coastal waters. Part V: Bacillarophyceae (diatoms). Fish. Invest. Minist. Agric. Fish. Food (G. B.) Ser. IV.

Hustedt, F. 1927-1966. Die kieselalgen Deutschlands, Österreichs und der Schweiz. In L. Rabenhorst, ed. KryptogamenFlora von Deutschland, Österreich und der Schweiz, 7. Akademishe Verlagsgesellschaft, Leipzig.

. 1955. Marine littoral diatoms of Beaufort, North Carolina. Duke Univ. Mar. Stn. Bull. 6:1-67.

López Fuerte, F. O. 2004. Estructura de asociaciones de diatomeas en sedimentos del intermareal en la zona noroeste del Sistema lagunar Magdalena-Almejas, B.C.S., México. M.S. thesis, Centro Interdisciplinario de Ciencias Marinas, Instituto Politécnico Nacional, La Paz, B.C.S., México.

Magurran, A. E. 1988. Ecological diversity and its measurement. Princeton University Press, Princeton, New Jersey.

Main, S., and C. D. McIntire. 1974. The distribution of epiphytic diatoms in Yaquina Estuary, Oregon, U.S.A. Bot. Mar. 17:8899.

Maples, R. S. 1983. Community structure of diatoms epiphytic on pneumatophores of the black mangrove Avicennia germinans in a Louisiana salt marsh. Gulf Res. Rep. 7 (3): $255-259$.

Martínez López, A., and G. Verdugo Díaz. 2000. Composición y dinámica del fitoplancton en el BAC de Bahía Magdalena, B.C.S. Pages 125-142 in D. Lluch Belda,
J. Elorduy Garay, S. Lluch Cota, and G. Ponce Díaz, eds. BAC: Centros de actividad biológica del Pacífico mexicano. Centro de Investigaciones Biológicas del Noroeste, Centro Interdisciplinario de Ciencias del Mar, Consejo Nacional de Ciencia y Tecnología, La Paz, B.C.S., México.

Martínez López, A., D. A. Siqueiros Beltrones, and N. Silverberg. 2004. Offshore transport of benthic diatoms beyond the continental shelf of the Baja California peninsula. Cienc. Mar. 30: (in press).

McIntire, C. D., and W. W. Moore. 1977. Marine littoral diatoms: Ecological considerations. Pages 333-371 in D. Werner, ed. The biology of diatoms. Botanical Monographs. University of California Press, Berkeley.

McIntire, C. D., and W. S. Overton. 1971. Distributional patterns in assemblages of attached diatoms from Yaquina Estuary, Oregon. Ecology 52:758-777.

McIntire, C. D., and C. W. Reimer. 1974. Some marine and brackish-water $A c h-$ nanthes from Yaquina Estuary, Oregon (U.S.A.). Bot. Mar. 17:164-175.

Moreno, J., S. Licea, and H. Santoyo. 1996. Diatomeas del Golfo de California. Universidad Autónoma de Baja California Sur, Secretaría de Educación Pública, Fondo para la Modernización de la Educación Superior, Programa Interdisciplinario e Interinstitucional Mar de Cortés, La Paz, B.C.S., México.

Navarro, N. J. 1982. Marine diatoms associated with mangrove prop roots in the Indian River, Florida, U.S.A. Bibl. Phycol. 61:1-151.

1987. Diatomeas epífitas de Puerto Rico I. Grammatophora oceanica Ehr. var. oceanica. Science-Ciencia 14 (1): 13-18.

- 1988. Diatomeas en tapetes microbianos de Puerto Rico. Gayana Bot. 45 (14): $275-281$.

Navarro, N. J., and R. Torres. 1987. Distribution and community structure of marine diatoms associated with mangrove prop roots in the Indian River, Florida, U.S.A. Nova Hedwigia 45:101-112.

Obeso Nieblas, M., J. H. Gaviño Rodríguez, 
and A. R. Jiménez Illescas. 1999. Modelación de la marea en el sistema lagunar Bahía Magdalena-Almejas, B.C.S., México. Oceánides 14 (2): 79-88.

Peña, E. J., R. Zingmark, and C. Nietch. 1999. Comparative photosynthesis of two species of intertidal epiphytic macroalgae on mangrove prop roots during submersion and emersion. J. Phycol. 35:12061214.

Peragallo, H., and M. Peragallo. 1897-1908. Diatomées marines de France et districts maritimes voisins. Ed. M. J. Tempere, France.

Pielou, E. C. 1975. An introduction to mathematical ecology. Wiley Inter-Science, New York.

Reyes-Vázquez, G. 1975. Diatomeas litorales de la familia Naviculaceae, de la laguna $\mathrm{La}$ Restinga, Isla Margarita, Venezuela. Bol. Inst. Oceanogr. Univ. Oriente Cumana 14 (2): 199-225.

Riosmena Rodríguez, R., and D. A. Siqueiros Beltrones. 1996. Morfología y distribución de Corallina vancouverensis (Corallinales, Rhodophyta) en el noroeste de México. Cienc. Mar. 21 (2): 187-199.

Round, F. E., and L. Bukhtiyarova. 1996. Four new genera based on Achnanthes (Achnantbidium) together with a redefinition of Achnanthidium. Diatom Res. 11 (2): 345-361.

Round, F. E., R. M. Crawford, and D. G. Mann. 1990. The diatoms: Biology and morphology of the genera. Cambridge University Press, Cambridge.

Sánchez Rodríguez, I., C. Fajardo León, and C. Oliveiro Pantoja. 1989. Estudio florístico estacional de las algas en Bahía Magdalena, B.C.S., México. Invest. Mar. Cent. Interdiscip. Cienc. Mar. 4 (1): 35-48.

Sanders, H. L. 1960. Benthic studies in Buzzards Bay. III. The structure of softbottom community. Limnol. Oceanogr. 5:138-153.

SAS Institute. 2001. JUMP in version 4.0.4. SAS Institute, Inc. Cary, South Carolina.

Schmidt, A., M. Schmidt, F. Fricke, H. Heiden, O. Muller, and F. Hustedt. 18741959. Atlas der diatomaceenkunde. Heft 1-120, Tafeln 1-460. Reisland, Leipzig.
Shannon, C., and W. Weaver. 1949. The mathematical theory of communication. University of Illinois Press, Urbana.

Simonsen, R. 1987. Atlas and catalogue of the diatom types of F. Hustedt I, II, III. J. Cramer, Berlin, Germany.

Siqueiros Beltrones, D. A. 1990. A view of the indices used to assess species diversity in benthic diatom associations. Cienc. Mar. 16 (1): 91-99.

. 1998. Statistical treatment of Shannon-Wiener's diversity index $\left(\mathrm{H}^{\prime}\right)$ : Tests of normality for sample values of diatom assemblages. Oceánides 13 (1): 111 .

- 2000. Benthic diatoms associated with abalone (Haliotis spp.) on a rocky substratum from Isla Magdalena, Baja California Sur, México. Oceánides 15 (1): 35-46.

. 2002. Diatomeas bentónicas de la península de Baja California: Diversidad y potencial ecológico. Universidad Autónoma de Baja California Sur, Centro Interdisciplinario de Ciencias del Mar, Instituto Politécnico Nacional, La Paz, B.C.S., México.

Siqueiros Beltrones, D., and S. IbarraObando. 1985. Lista florística de las diatomeas epífitas de Zostera marina en Bahía Falsa, San Quintin. Cienc. Mar. 11 (3): 21-67.

Siqueiros Beltrones, D. A., and F. O. LópezFuerte. 2003. Epiphytic diatoms on red mangrove (Rhizophora mangle L.) prop roots in Bahía Magdalena, B.C.S, México. Biol. Trop. 51: (in press).

Siqueiros Beltrones, D. A., and H. Morzaria Luna. 1999. New records of marine benthic diatom species for the North-Western Mexican region. Oceánides 14 (2): 89-95.

Siqueiros Beltrones, D. A., and E. SánchezCastrejón. 1999. Structure of benthic diatom assemblages from a mangrove environment in a Mexican subtropical lagoon. Biotropica 31 (1): 48-70.

Sullivan, M. J. 1981. Community structure of diatoms epiphytic on mangroves and Thalassia in Bimini Harbour, Bahamas. Pages 385-398 in R. Ross, ed. Proceedings of the 6th Diatom Symposium, Budapest. 
Tanaka, N. 1986. Adhesive strength of epiphytic diatoms on various seaweeds. Bull. Jpn. Soc. Sci. Fish. 52 (5): 817-821.

Tanaka, N., and A. Asakawa. 1986. Epiphytic diatom flora on a brown alga, Sargassum borneri, from various localities. Bull. Natl. Res. Inst. Aquacult. 9:59-63.

Wah, T. T., and C. Wee. 1988. Diatoms from mangrove environments of Singapore and southern peninsular Malaysia. Bot. Mar. 31:317-327.

Witkowski, A., H. Lange-Bertalot, and D. Metzeltin. 2000. Diatom flora of marine coasts. In H. Lange-Bertalot, ed. Iconographia diatomologica. Vol. 7. Koeltz Scientific Books.

\section{Appendix}

List of (171) Epiphytic Diatom Taxa from Red Mangrove (Rhizophora mangle) Prop Roots in Bahía Magdalena, B.C.S., México

\begin{tabular}{|c|c|}
\hline Species & Species \\
\hline Acbnanthes brevipes var. angustata (Greville) Cleve* & Caloneis permagna (Bailey) Cleve \\
\hline Achnanthes brevipes var. intermedia (Kützing) Cleve & Campylodiscus samoensis Grunow* \\
\hline Acbnanthes brevipes var. parvula (Kützing) Cleve & Campylodiscus thuretii Brébisson \\
\hline Achnanthes groenlandica var. phinneyi McIntire \& Reimer & Catacombas gaillonii (Bory) Williams \& Round \\
\hline Achnanthes cf. kuwaitensis var. parvula McIntire \& & Catenula adhaerens Mereschkowsky \\
\hline Reimer & Cocconeis diminuta Pantocsek \\
\hline Achnanthes manifera Brun & Cocconeis dirupta Gregory \\
\hline Acbnanthes parvula Kützing & Cocconeis dirupta var.? \\
\hline Acbnanthes suchlandtii Hustedt* & Cocconeis dirupta var. flexella (Janisch \& Rabenhorst) \\
\hline Achnanthes yaquinensis McIntire \& Reimer & Grunow \\
\hline Achnanthidium minutissima Kützing & Cocconeis diruptoides Hustedt \\
\hline Achnantbidium sp. 1 & Cocconeis distans (Gregory) A. Schmidt \\
\hline Actinoptychus adriaticus Grunow & Cocconeis peltoides Hustedt \\
\hline Actinoptychus aster Brun & Cocconeis placentula Ehrenberg \\
\hline Actinoptychus splendens (Shadbolt) Ralfs & Cocconeis pseudomarginata Gregory \\
\hline Amphora acutiuscula Kützing & Cocconeis scutellum var. scutellum Ehrenberg \\
\hline Amphora bigibba Grunow & Cocconeis scutellum var. parva Grunow \\
\hline Amphora cingulata Cleve* & Coscinodiscus radiatus Ehrenberg \\
\hline Amphora clevei Grunow & Cyclotella kutzingiana Chauvin** \\
\hline Amphora coffeaeformis (Agardh) Kützing & Cyclotella litoralis Lange \& Syvertsen \\
\hline Amphora coffeaeformis var. salina (W. Smith) Cleve & Cyclotella striata (Kützing) Grunow \\
\hline Amphora costata W. Smith & Cyclotella sp. 1 \\
\hline Amphora elegantula Hustedt* & Cymatoneis circumvallata Cleve* \\
\hline Amphora exigua Gregory & Cymbella subturgida Gregory \\
\hline Amphora obtusa var. oceanica Castracane & Cymbella ventricosa Kützing \\
\hline Amphora obtusa var. rectangulata Peragallo* & Delphineis surirella (Ehrenberg) Andrews \\
\hline Amphora ocellata Donkin & Diadesmis cf. contenta Grunow \\
\hline Amphora proteus Cleve & Dimeregramma maculatum (Cleve) Frenguelli \\
\hline Amphora proteus var. contigua Cleve & Dimeregramma minor var. minor (Gregory) Ralfs \\
\hline Amphora proteus var. kariana Grunow & Diploneis chersonensis (Grunow) Cleve \\
\hline Amphora robusta var. bemicostata Peragallo* & Diploneis crabro Ehrenberg \\
\hline Amphora salina var. tenuissima Hustedt & Diploneis gravelleana Hagelstein \\
\hline Amphora sp. 1 & Diploneis gruendleri (A. Schmidt) Cleve \\
\hline Astartiella punctifera (Hustedt) Witkowski, Lange- & Diploneis litoralis (Donkin) Cleve \\
\hline Bertalot \& Metzeltin & Diploneis obliqua (Brun) Hustedt \\
\hline Auliscus caelatus Bailey & Diploneis smithii (Brébisson) Cleve \\
\hline Auliscus punctatus Bailey & Diploneis splendida Gregory \\
\hline Bacillaria paxillifer (Müller) Hendey & Diploneis suborbicularis (Gregory) Cleve \\
\hline Biddulphia alternans (Bailey) van Heurck & Diploneis vacillans (A. Schmidt) Cleve \\
\hline Caloneis elongata (Grunow) Boyer & Eunotograma laeve Grunow \\
\hline Caloneis latiuscula f. minor (Kützing) Cleve* & Fallacia forcipata (Greville) Stickle \& D. G. Mann \\
\hline Caloneis liber (W. Smith) Cleve & Fallacia litoricola (Hustedt) D. G. Mann \\
\hline Caloneis linearis (Grunow) Boyer & Fallacia nummularia (Greville) D. G. Mann \\
\hline
\end{tabular}


Appendix (continued)

\begin{tabular}{|c|c|}
\hline Species & Species \\
\hline Fallacia pygmaea (Kützing) Stickle \& D. G. Mann & Nitzschia subvitrea Hustedt \\
\hline Fallacia vittata (Cleve) D. G. Mann & Nitzschia vitrea Norman \\
\hline Gomphonemopsis pseudexigua (Simonsen) Medlin & Nitzschia sp. 1 \\
\hline Grammatophora marina Ehrenberg & Odontinium marinum Grunow \\
\hline Gyrosigma balticum (Ehrenberg) Rabenhorst & Opephora marina (Gregory) Petit \\
\hline Hantzschia virgata (Roper) Grunow & Opephora pacifica (Grunow) Petit \\
\hline Huttoniella reichardtii Grunow* & Opephora schwartzii Petit \\
\hline Hyalosynedra laevigata (Grunow) Williams \& Round & Oestrupia powellii var. vidovichii (Grunow) Heiden \\
\hline Lyrella approximatoides Hustedt & Paralia sulcata var. sulcata (Ehrenberg) Cleve \\
\hline Lyrella clavata var. subconstricta (Gregory) D. G. Mann & Paralia sulcata var. radiata Grunow \\
\hline Lyrella exsula (A. Schmidt) D. G. Mann & Petroneis granulata (Bailey) D. G. Mann \\
\hline Lyrella irrorata (Greville) D. G. Mann & Plagiogramma pulchellum var. pygmaea Greville \\
\hline Navicula agnita Hustedt & Plagiotropis vitrea (W. Smith) Kuntze \\
\hline Navicula auriculata Hustedt & Planothidium delicatulum var. subcapitata (Östrup) Round \\
\hline Navicula cancellata Donkin & \& Bukhtiyarova \\
\hline Navicula diversistriata Hustedt & Planotbidium hauckianum (Grunow) Round \& \\
\hline Navicula grimmei Krasske* & Bukhtiyarova \\
\hline Navicula longa Gregory & Planotbidium lanceolatum (Brébisson) Round \& \\
\hline Navicula parva (Meneghini) A. Cleve & Bukhtiyarova \\
\hline Navicula parvillardi Hustedt & Pleurosigma formosum $\mathrm{W}$. Smith \\
\hline Navicula pennata Schmidt & Pleurosigma salinarum Grunow \\
\hline Navicula platyventris Meister & Podosira montagnei Kützing \\
\hline Navicula salinarum Grunow & Psammodyction bombiforme (Grunow) D. G. Mann* \\
\hline Neodelphineis pelagica Takano & Psammodyction constrictum (Kützing) D. G. Mann \\
\hline Nitzschia amphibia Grunow & Psammodyction panduriforme (Gregory) D. G. Mann \\
\hline Nitzschia angularis $W$. Smith & Rhaphoneis nitida (Gregory) Grunow \\
\hline Nitzschia brittoni Hustedt & Seminavis sp. 1 \\
\hline Nitzschia denticula Grunow & Seminavis sp. 2 \\
\hline Nitzschia dissipata (Kützing) Grunow & Staurophora amphioxys (Gregory) D. G. Mann \\
\hline Nitzschia fasciculata Grunow & Staurosirella pinnata (Ehrenberg) Williams \& Round \\
\hline Nitzschia frustulum var. frustulum (Kützing) Grunow & Surirella fastuosa var. fastuosa Ehrenberg \\
\hline Nitzschia frustulum var. perminuta Grunow & Surirella fastuosa var. suborbicularis Grunow* \\
\hline Nitzschia gandersheimiensis Krasske* & Tabularia tabulata var. affinis (Kützing) A. Cleve \\
\hline Nitzschia gracilis Hantzsch & Tabularia tabulata var. parva (Hustedt) Lange-Bertalot \\
\hline Nitzschia granulata (Grunow) D. G. Mann & Terpsinoë americana (Bailev) Ralfs \\
\hline Nitzschia grossestriata Hustedt & Thalassionema nitzschioides (Grunow) Hustedt \\
\hline Nitzschia hybridaeformis Hustedt & Thalassiosira sp. 1 \\
\hline Nitzschia lanceolata var. minor Grunow & Trachyneis aspera Ehrenberg \\
\hline Nitzschia longa Grunow & Trachyneis clepsydra (Donkin) Cleve \\
\hline Nitzschia longissima var. parva (Brébisson) Ralfs & Trachyneis velata A. Schmidt \\
\hline Nitzschia obtusa var. obtusa W. Smith & Triceratium favus Ehrenberg \\
\hline Nitzschia obtusa var. parva Hustedt & Tryblionella acuminata Wm. Smith \\
\hline Nitzschia obtusa var. scalpelliformis Grunow & Tryblionella apiculata Gregory \\
\hline Nitzschia ovalis Arnott* ${ }^{*}$ & Tryblionella compressa (Bailev) Poulin \\
\hline Nitzschia sigma (Kützing) W. Smith & Tryblionella navicularis (Brébisson ex Kützing) Ralfs \\
\hline Nitzschia socialis Gregory & \\
\hline
\end{tabular}

* New records for the Baja California peninsula. 